\title{
IDENTIFICATION AND ASSESSMENT OF THE PROBLEM OF LOCAL STAKEHOLDERS ENGAGED IN BRACKISH WATER FISHERIES OF SANDESHKHALI I BLOCK, NORTH 24 PARGANAS, WEST BENGAL, INDIA
}

\author{
Pradip Chandra Patra \\ Assistant Professor, Department of Geography, Sivanath Sastri College, Kolkata, India \\ Email: pradippatra5@gmail.com
}

\begin{abstract}
The brackish water fishery of West Bengal has gained exceptional ground in the previous couple of decades; it is as yet confronting diverse problems and challenges which are remaining in transit of its development and improvement. In this study, the primary focus is on the principle problem of brackish water fishery as seen by the local stakeholders and shrimp/fish farmers of brackish water fishery. In that capacity an exploration study has been attempted on Shrimp and Fish Farmers Cum Fishery Owners, Fishery Owners, Different engaged labour in Brackish water fishing, Traders and Wholesalers, Land Leaser and Aratder/Moneylender of the brackish water farming areas. These six categories of local stakeholders are identified with the problem of Brackish Water Fishery in Sandeshkhali I. An aggregate of 578 local stakeholders were selected to respond my survey questionnaire. The author suggests that problems including high mortality rate, lack of virus screening facility and the unfair practices should be taken into consideration to represent both the operative and key level immediately. These problems have the immediate bearing on the activities, living standards of the local stakeholders and shrimp/fish farmers of the brackish water fishery the vast majority of who have a place with discouraged areas of society.
\end{abstract}

Key words: Shrimp, Brackish Water Fishery. Shrimp/Fish Farmers, Fishery Owners

\section{Introduction}

The fisheries made through ages in tidal wet lands of brackish water, specifically mudflats, swamps, marshes, paddy fields, etc., are locally known as bhasabadha' or 'bheries' or 'ghery' in the territory of North 24-Parganas, West Bengal. This traditional fishery is represented to have originally made in spill zone of the Bidhyadhari river close Calcutta city, which was silted up due to sewage discharge in it. A touch of the river and spillway were embanked and changed over into lucrative bheri fisheries. Later this fishery has been developed the lower deltaic territory of 'west Bengal known as the Sunderbans with the improvement of transport offices (Saha. G.N. et.al. 1986). The aquaculture exercises in the State of West Bengal, traditional brackish water aquaculture exercises in the "Bheries" of Sunderban zones are ruling the scene and the spread of brackish water aquaculture would help elevate the financial state of the needy people of the Sunderbans zones (Ghosh and Chakraborty,1989). The Sunderban regions return from fisheries is higher than that from agriculture and fisheries improvement is basic for supportable advancement of the Sunderban Delta, highest need ought to be given to the advancement of freshwater and mostly brackish water fisheries so as to create pay, work and riches in the region (Sharma, 1994). The principle issues of brackish water fish culture rehearsed in the estuaries of the Ganga is to control the over-saltiness of the water. There was significant extent of broadening brackish water fish cultivating and paddy-cum-fish culture in the low-lying zones of the Sunderbans. The misuse of the poor fishers by the go between who advance credit to them during the off-season on condition that every one of their gets would need to be sold to them at a fixed value which is extremely low. In the event of shrimp culturists and crab-catchers of the Sunderbans, the framework is as yet common (Hora 1952). Brackish water shrimp culture is probably going to rise as the most noteworthy marvel of the situation of fisheries advancement in India during the next decade, inferable from driving force from the export market. (Kalawar, A.G, et al 1988). The shrimp has been presented and cultivated in Asia since the mid-1990s, (Balakrishnan et al, 2011). The shrimp production has developed at marvellous rate during the year 1992-1994 and later begun diminishing because of outbreak of diseases, at the same time, the episode of viral illnesses has expanded the economic risks and moderated the development of industry(Flegel, 2006).Coastal Aquaculture production in the 
nation to a great extent because of shrimp cultivating is assessed that out of about 1.23 million ha distinguished as potential zones for brackish water fish cultivating in the nation, Of the complete territory, about 10 percent zone is being cultivated at present. Of this territory, about 80 percent is under traditional farming systems and the rest of the is under extensive and semi extensive shrimp cultivating. The activities of traditional shrimp cultivating through brackish water fishery on business scale are taken up in the states of West Bengal.

\section{Study Area}

Location of the study area is Sandeshkhali I CD Block is part of the North Bidyadhari Plain, limited by Minakhan and Hasnabad CD Blocks in the north, Hingalganj CD Block in the east, Sandeshkhali II CD Block in the south and Bhangar II and Bhangar I CD Blocks in South 24 Parganas locale in the west. The territory is loaded with full of marshes and salt water lakes. It has 8-gram panchayats, these are Bayermari I, Kalinagar, Sarberia Agarhati, Bayermari II, Nazat I, Sehera Radhanagar, Hatgachhi and Nazat. Nazat police headquarters serves this square. Home office of this CD Block is at Nazat. North 24 Parganas is covered with brackish water areas constituting 58 percent (33949 hectors, 2017-2018) of the total brackish water resources of West Bengal and Sandeshkhali-I block is the second highest of the district occupied of brackish water area which is 16.32 percent and there is a heavy concentration of brackish water area in the block. The Sandeshkhali-I block has vast brackish water (Area 5541.11in hector, 2017-18) areas of varied nature suitable for shrimp and fish culture; it has huge human resources to utilize the vast fishery resources available in the block. But the paradox is that the state has to depend on the supply of fish from other states of the country and even from abroad to meet its own demand. It is, thus obvious that the industry is suffering from some formidable problems which are standing on the way of its quick development for utilizing the huge resources available. Hence, as we should see it Sandeshkhli I block of North 24 Parganas is an ideal area for the pinpointing problem of brackish water fishery development.

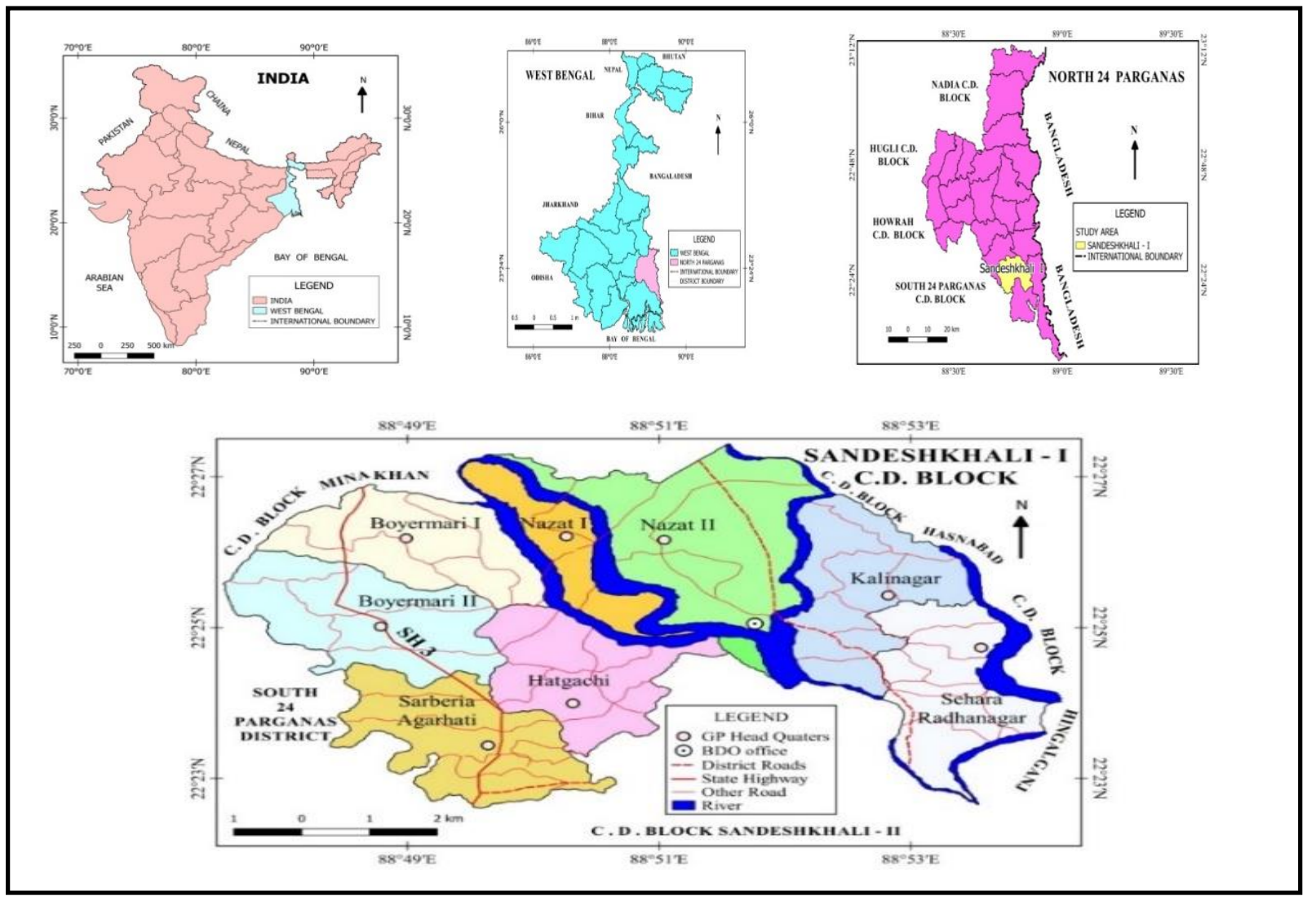

\section{Objectives of the Study}

The main objectives of the study are as follows:

- To analyse the current status of the Brackish Water Fishery in Sandeshkhali-1 block, West Bengal.

- To identify the problems those affected the local stakeholders of Brackish Water Fishery.

- To provide some recommendations for cultivating shrimp and fishes of Brackish water Fishery in Sandeshkhali-I Block in West Bengal. 


\section{Limitations of the Study}

We can identify the following limitations of our study which should be taken into consideration for meaningful interpretation and proper application of results of the investigation. From this perspective, we can visualize the following limitations.

i. While recognizing the issues of brackish water fishery development, we needed to stress on the financial parts of the fishermen as well the industry. The social issues of the neighbourhood stakeholders, for example, lack of education, casteism, shortage of lighting, need of road communication safe drinking water and so forth couldn't be considered. However, these are likewise identified with the problems of brackish water fishery development.

ii. We could just cover the brackish water fishery sector which supplies over 90 percent of the produce and employ the same percentage of population.

iii. Reluctance of the various respondents to experience a survey procedure was the main restriction of this survey.

iv. The dimension of lacking of education among the most of the stakeholders was a noteworthy obstruction to gather reliable information

\section{Methodology}

Both primary and secondary sources were utilized for the gathering of important information. Primary data were gathered through questionnaire survey. Utilization of secondary data was carefully constrained to the background discussion of the research, the structuring of the report and development of the survey question. The data have been analysed using suitable statistical (SPSS)/ quantitative Method.

\section{Research Approach}

The scholar has identified the problem of brackish water fishing in the investigation region by at first led a pilot overview at Sandeshkhali- I block where interfaced with number of people who connected with themselves directly or indirectly way in brackish water fishing in regards to different issue in this sector. By that way twelve areas of problem, which were coming out most of the time in discussion have been distinguished, coming out most of the time in discussion, have been identified. These are A) High mortality rate and lack of virus screening facilities of shrimp B) Financial Problems (Less opportunity of finance) C) Uncertain and non-remunerative Price (depends on demand and prawn size) D) Lack of attention and contribution of the Government E) Robbery/Unsocial activities F) Brackish water facilities G) Embankment(River side bhery), Dyke (between two ghery/bhery) failure $\mathrm{H}$ ) Land leasing problem I) Labour Problem J) Political disturbance K) Unethical practice L) Natural Calamities. To collect the data from the target group, a structured questionnaire had been followed. Primary data have been gathered through interviewing the respondents in their respective workplaces. Twelve unique of problems in local stakeholders of brackish water fisheries the Sandeshkhali-1 block area have been determined in the questionnaire to comprehend the view of nearby stakeholders over the needs of such problem. For this, through the questionnaire the respondents have been approached to give ranks $1,2,3,12$ to the predefined problem considering the relative gravity of such problem. The questionnaires had been used to collect the data from specified local stakeholders such as from the Farmers cum Ghery Owners, Ghery Owners, Traders \& Wholesalers; Different labour related brackish water fish farming, Land Leaser, Aratder of brackish water fishery.

\section{Local Stakeholders of Brackish Water Fishery in the Study Area}

I have identified some local stakeholders on the basis of filed survey who engaged themselves directly or indirectly in brackish water fishing. These are Farmers cum Ghery/Bhery Owners, Ghery/Bhery Owners, labour and depot worker, Traders, Exporter, Land Leaser, Prawn seed catchers, Prawn seed suppliers, Hatchery owners, Local fish pickers, Fish Catchers, Pata, Atol, Boats etc. makers, Aratder, Moneylender, Technical Experts, Managerial staff, Ice Producers, Consumers, Fertilizer suppliers, Government, local stakeholders of brackish water fishery.

\section{Area of Brackish Water}

Our nation is blessed to have immense potential assets in the inland fisheries area, as tanks and ponds, reservoirs, brackish water, estuaries, lagoons, rivers and canals. According to the Indian Institute of Management, Ahmadabad (IIMA,1983) the potential is:(a) 7.53 lakh hectares of ponds (b) 975 major reservoirs with 17 lakh hectares in 12 states (c) 9.02 lakh hectares of brackish water. (d) $29000 \mathrm{~km}$. of rivers and canals. 
Table: 01 Brackish Water Area of Sandeshkhali and Sandeshkhali-I Block.

\begin{tabular}{|c|c|c|c|c|c|}
\hline Block & $\begin{array}{l}\text { Total } \\
\text { Area in } \\
\text { Hector }\end{array}$ & $\begin{array}{l}\text { Area under } \\
\text { Brackish Water } \\
\text { Bheri during } \\
1980-1981 \text { in } \\
\text { Hector }\end{array}$ & $\begin{array}{l}\text { Area under } \\
\text { Brackish } \\
\text { Water Bheri } \\
\text { during 2017- } \\
2018 \text { in } \\
\text { Hectare }\end{array}$ & $\begin{array}{l}\text { \% of } \\
\text { Brackish } \\
\text { Water Bheri } \\
\text { to Total Area } \\
\text { during 1980- } \\
1981 \text { in }\end{array}$ & $\begin{array}{l}\text { \% Brackish } \\
\text { Water of } \\
\text { Bheri Area to } \\
\text { Total Area } \\
\text { during 2017- } \\
2018\end{array}$ \\
\hline Sandeshkhali & 37951 & 1789 & - & 4.71 & - \\
\hline Sandeshkhali-I & 18230 & - & 5541.11 & - & 30.40 \\
\hline Sandeshkhali-II & 19721 & - & 2411.8 & - & 12.23 \\
\hline Sandeshkhali & 37651 & 1789 & 7952.91 & 4.71 & 21.12 \\
\hline
\end{tabular}

Source: Ghosh, 1990 and Hand Book Of Fisheries Statistics, 2017-2018, West Bengal

From above table it is clear that, Sandeshkhali block has 1789 hectare Bheri during the period form 1980-1980 which is 4.71 percent. and during the period form 2017-2018

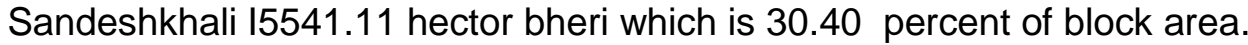

\section{Result and Discussion}

Problems of Brackish Water Bhery/Ghery/Fishery based on the perception of the sample fishermen or Discoveries about view of the of the sample fishermen in regards to problem of brackish water fisheries

\section{Brackish Water farmers cum Ghery/Bhery owners of Sandeshkhali I block}

From the scree plot it can be seen that the curve starts flattering from $4^{\text {th }}$ factor onwards. The rotated component matrix shows (table no.2) the loadings of the 12 (twelve) variables on the 4 (four) factors extracted.

Table 02: Rotated Component Matrix

\begin{tabular}{|c|c|c|c|c|}
\hline & \multicolumn{4}{|c|}{ Component } \\
\hline & 1 & 2 & 3 & 4 \\
\hline$A$ & & -.951 & & \\
\hline B & & -.883 & & \\
\hline$C$ & .792 & & & \\
\hline$D$ & .887 & & & \\
\hline E & .856 & & & \\
\hline $\mathrm{F}$ & & & & .952 \\
\hline G & & & .852 & \\
\hline $\begin{array}{l}\mathrm{H} \\
\mathrm{l}\end{array}$ & -.653 & & .877 & \\
\hline$J$ & & .505 & & -.507 \\
\hline K & -.579 & & -.541 & \\
\hline $\mathrm{L}$ & -.691 & .513 & & \\
\hline
\end{tabular}

Extraction Method: Principal
Figure 2: Scree plots for Ghery/Bhery owners

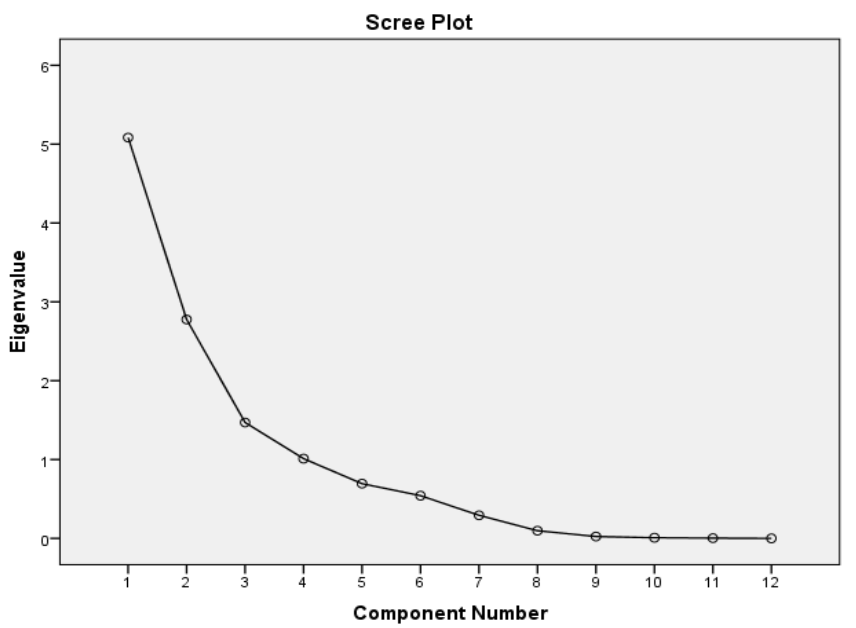

\section{Component Analysis}

The higher the absolute value of the loading, the more the factors contributes to the variable. Here 4(four) factors have extracted from 12 (twelve) variables where Brackish water facilities is substantially loaded on factor 4 (four), Land leasing problem and Embankment (River side bhery), Dyke (between two ghery/bhery) failure, are substantially loaded on factor 3 (three), High mortality rate and lack of virus screening facilities and Financial Problems (Less opportunity of finance) are substantially loaded on factor 2 (two) and all the remaining's are substantially loaded on factors 1(one) can be used as variables for further analysis.

\section{Ghery/Bhery Owners of Sandeshkhali I Block}

From the scree plot it can be seen that the curve starts flattering from $6^{\text {th }}$ factor onwards. Th e rotated component matrix shows (table no.3) the loadings of the 12 (twelve) variables on the 4 (four) factors extracted. The higher the absolute value of the loading, the more the factors contributes to the variable. Here 4(four) factors have extracted from 12 (twelve) variables where Labour Problem and Embankment (River side bhery), Dyke (between two ghery/bhery) failure 
are substantially loaded on factor 4 (four), Land leasing problem and Financial Problems (Less opportunity of finance)are substantially loaded on factor 3 (three), High mortality rate and lack of virus screening facilities, Lack of attention and contribution of the Government and Political disturbance are substantially loaded on factor 2 (two) and all the remaining's are substantially loaded on factors 1 (one) can be used as variables for further analysis.

Table 03: Rotated Component Matrix

\begin{tabular}{|c|c|c|c|c|}
\hline & \multicolumn{4}{|c|}{ Component } \\
\cline { 2 - 5 } & 1 & 2 & 3 & 4 \\
\hline A & & 0.946 & & \\
B & & & 0.85 & \\
C & 0.637 & & & \\
D & & 0.88 & & \\
E & 0.745 & & & \\
F & 0.916 & & & 0.737 \\
G & & & 0.902 & \\
H & & & & 0.78 \\
I & & & & -0.54 \\
J & & -0.59 & & \\
K & -0.719 & & & \\
L & -0.664 & & & \\
\hline
\end{tabular}

Extraction Method: Principal Compo. Analysis.
Figure 03: Scree plots for Ghery/Bhery Owners

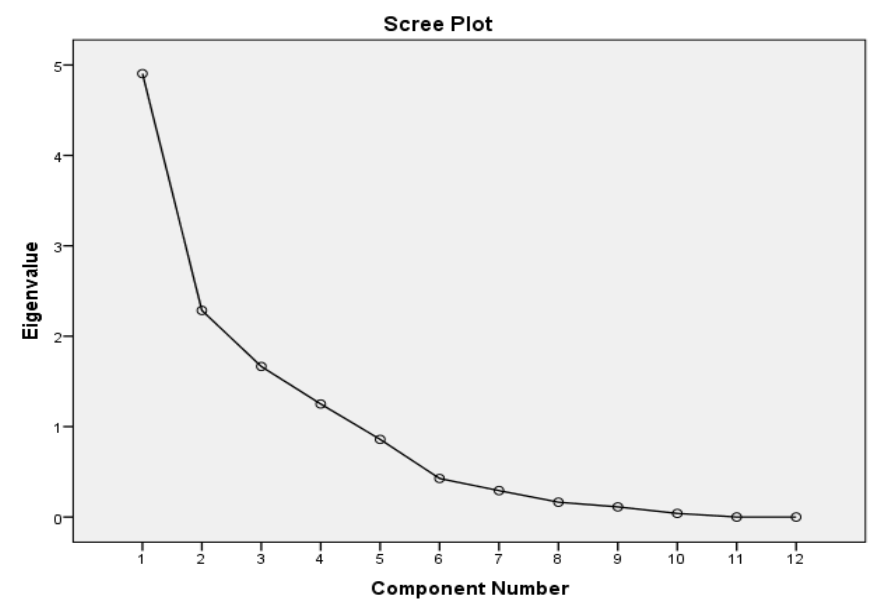

\section{Different engaged labour in Brackish water fishing of Sandeshkhali I Block}

From the scree plot it can be seen that the curve starts flattering from $7^{\text {th }}$ factor onwards. The rotated component matrix shows (table no.4) the loadings of the 12 (twelve) variables on the 4 (four) factors extracted. The higher the absolute value of the loading, the more the factors contributes to the variable. Here 4(four) factors have extracted from 12 (twelve) variables where Political disturbance is substantially loaded on factor 4 (four), Robbery/unsocial activities, Labour Problem are substantially loaded on factor 3 (three), Brackish water facilities and Land leasing problem are substantially loaded on factor 2 (two) all the remaining's are substantially loaded on factors 1(one) can be used as variables for further analysis. From the scree plot also, it can be seen that the curve starts flattering from $7^{\text {th }}$ factor onwards. The rotated component matrix shows (table no.3) the loadings of the 12 (twelve)

Table: 4 Rotated Component Matrix

\begin{tabular}{|l|l|l|l|l|}
\hline \multirow{2}{*}{} & \multicolumn{4}{|c|}{ Component } \\
\cline { 2 - 5 } & 1 & 2 & 3 & 4 \\
\hline $\mathrm{A}$ & .595 & & & \\
$\mathrm{~B}$ & .545 & & .753 & \\
$\mathrm{C}$ & .841 & & & \\
$\mathrm{D}$ & .765 & & & \\
$\mathrm{E}$ & & & -.851 & \\
$\mathrm{~F}$ & & .819 & & \\
$\mathrm{G}$ & & & & \\
$\mathrm{H}$ & & .809 & & \\
$\mathrm{I}$ & & & .544 & -.703 \\
$\mathrm{~J}$ & & & & -.895 \\
$\mathrm{~K}$ & -.664 & & & .536 \\
$\mathrm{~L}$ & & -.872 & & \\
\hline
\end{tabular}

Figure 04: Scree plots for Different engaged Labour

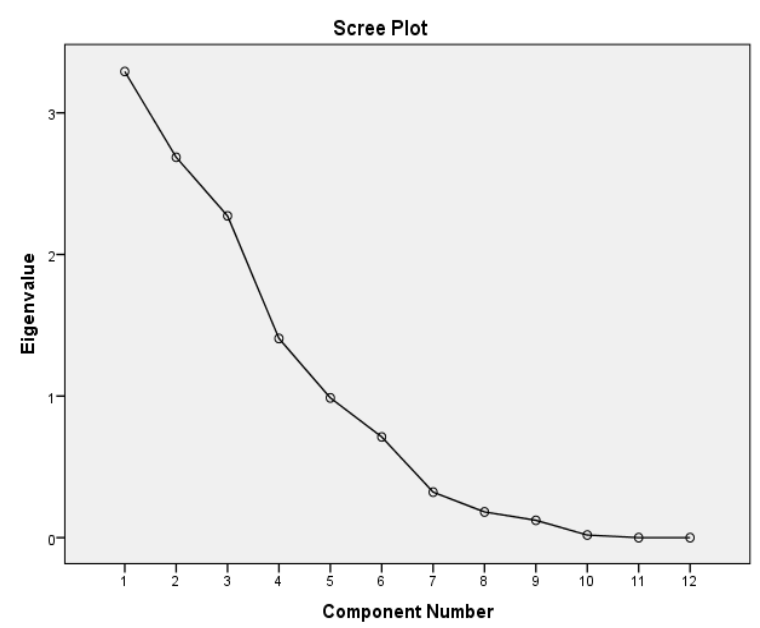

Extraction Method: Principal Component Analysis. 


\section{Land leaser of Sandeshkhali I Block}

From the scree plot it can be seen that the curve starts flattering from $3^{\text {th }}$ factor onwards

Table 05: Rotated Component

Matrix

\begin{tabular}{|l|l|l|l|l|}
\hline \multirow{2}{*}{} & \multicolumn{4}{|c|}{ Component } \\
\cline { 2 - 5 } & 1 & 2 & 3 & 4 \\
\hline $\mathrm{A}$ & .656 & & -.601 & \\
$\mathrm{~B}$ & .643 & .641 & & \\
$\mathrm{D}$ & & .692 & & \\
$\mathrm{E}$ & .801 & .661 & & \\
$\mathrm{~F}$ & & & & -.887 \\
$\mathrm{G}$ & & -.659 & & \\
$\mathrm{H}$ & & -.784 & & \\
$\mathrm{I}$ & & & .920 & \\
$\mathrm{~J}$ & & -.719 & & \\
$\mathrm{~K}$ & -.925 & & & \\
$\mathrm{~L}$ & -.755 & & & \\
\hline
\end{tabular}

Extraction Method: Principal Comp. Analysis
Figure 05: Scree plots for Land Leaser

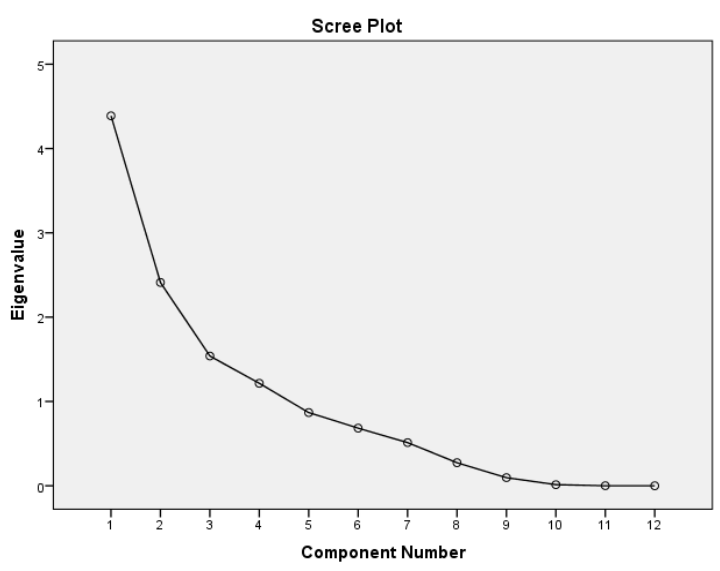

The rotated component matrix shows (table no.5) the loadings of the 12 (twelve) variables on the 4 (four) factors extracted. The higher the absolute value of the loading, the more the factors contributes to the variable. Here 4 (four) factors have extracted from 12 (twelve) variables where Brackish water facilities is substantially loaded on factor 4 (four), Labour Problem and High mortality rate and lack of virus screening facilities are substantially loaded on factor 3 (three) Land leasing problem, Political disturbance, Uncertain and nonremunerative Price(Depends on Prawn Size), Lack of attention and contribution of the Government and Embankment (River side bhery), Dyke (between two ghery/bhery) failure, are substantially loaded on factor 2 (two) all the remaining's are substantially loaded on factors 1 (one) can be used as variables for further analysis.

\section{Aratdar/Moneylenders of Sandeshkhali I}

From the scree plot it can be seen that the curve starts flattering from $5^{\text {th }}$ factor onwards.

Table 06: Rotated Component Matrix

\begin{tabular}{|l|c|c|c|l|}
\hline \multirow{2}{*}{} & \multicolumn{4}{|c|}{ Component } \\
\cline { 2 - 5 } & 1 & \multicolumn{1}{c|}{2} & 3 & 4 \\
\hline $\mathrm{A}$ & & & .584 \\
$\mathrm{~B}$ & & & .554 & .639 \\
$\mathrm{C}$ & .913 & & & \\
$\mathrm{D}$ & .672 & .580 & & \\
$\mathrm{E}$ & .788 & & & \\
$\mathrm{~F}$ & & & .814 & \\
$\mathrm{G}$ & & -.895 & & \\
$\mathrm{H}$ & -.704 & .527 & & \\
$\mathrm{I}$ & & & -.801 & \\
$\mathrm{~J}$ & -.674 & & & \\
$\mathrm{~K}$ & & -.776 & & \\
$\mathrm{~L}$ & & & -.564 & \\
\hline
\end{tabular}

Extraction Method: Principal Comp. Analysis
Figure 06: Scree plots for Aratdar/Money Lender

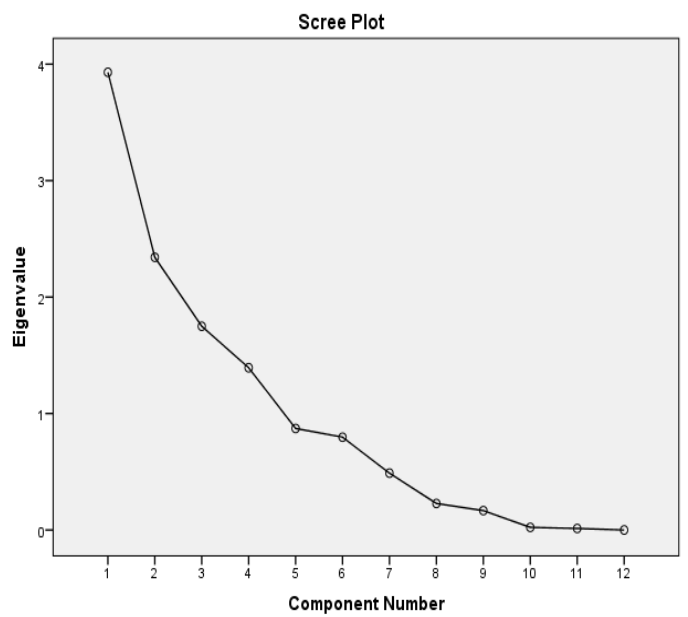

The rotated component matrix shows (table no.6) the loadings of the 12 (twelve) variables on the 4 (four) factors extracted. The higher the absolute value of the loading, the more the factors contributes to the variable. Here 4 (four) factors have extracted from 12 (twelve) variables where High mortality rate and lack of virus screening facilities are substantially loaded on factor 4 (four), Labour Problem, Brackish water facilities and Financial Problems (Less opportunity of finance) are substantially loaded on factor 3 (three) Embankment (River side bhery), Dyke (between two ghery/bhery) failure and Unethical practice 
are substantially loaded on factor 2 (two) all the remaining's are substantially loaded on factors 1 (one) can be used as variables for further analysis.

\section{Suggestion}

A) In regard to the problem - 'High mortality rate and lack of virus screening facilities of shrimp': To comprehend the problem in subtleties the Department of fisheries, West Bengal, ought to construct virus screening facility centre first at Nazat and Hatgachi of Sadeshkhali-I block. Artificial hatchery of prawn seeds should be built adjacent part of brackish water fishery and proper training of the brackish water fisher men may reduce mortality rate of shrimp. B) In regard to the problem - 'Financial Problems (Less opportunity of finance)': The Government of West Bengal should take initiative so that the brackish water fisher men take loan at subsidized rate and easy repayment schedule from the local Nationalised. In this way, they may lessen their reliance on Aratder and Moneylenders also. C) In regard to the problem - 'Uncertain and non-remunerative Price (depends on demand and prawn size)': It is suggested that cold storage should be built at Nazat and Hatgachi of Sandeshkhali I block to match the supply shrimp and fishes with its demand and thus to reduce the uncertainty of price. D) In regard to the problem - 'Lack of attention and contribution of the Government': Keeping the point of development of brackish water fishery in mind, the Department of fisheries, Govt. of West Bengal should decide how far scientifically and environmentally friendly technology in this respect is necessary. For this purpose, the Department should consult with experts as well as the local fishermen/ producers, scientist, government officers, etc. E) In regard to the problem 'Robbery/Unsocial activities': To understand the problem in details the department of fisheries west Bengal should first interact with the local brackish water fishermen especially of Hatcahhi, Bayermari and Sarberia of Sandeshkhali I block and this department should consult the local police station to take necessary action in this regard. Regular patrolling by local police is needed to solve the problem. F) In respect of the problem - 'Brackish water facilities': The Govt of west Bengal should be build more cannel where the fishery is situated far from the river and the brackish water can be distributed through this canal over the area. G) In regard to the problem - 'Embankment (River side bhery), Dyke (between two ghery/bhery) failure': The Government of West Bengal and Fishery Owners should take initiative to take measurements to proper maintain river embankment where brackish water fishery is situated adjacent part of the river embank. H) In regard to the problem - 'Land leasing problem': The owners of land give the land lease to fishery owners for 3 years or 5 years amounting to Rs $9000-12000$ per year through auctioning system this auctioning system is influenced by local political party. The department of fisheries west Bengal and local police station to take necessary action in this regarding regard to the problem - 'Political disturbance': The Government of West Bengal and local police station should take necessary steps to control the political disturbance at the time of different general election and all over the time. J) In regard to the problem - 'Labour problem': So as to elevate the living conditions of the fishing populace, a greater amount of infrastructural facilities ought to be outfitted, which will thus lessen their strains and stress for their better living of standard in the villages. Giving business chances to different engaged labour in brackish water fishing, during the lean season, will empower them to limit their borrowings, to meet out the utilization consumption partially. K) In regard to the problem - 'Unethical practice': At some point some deceptive shrimp producers and businessmen's malpractices like pushing the shrimp into unhygienic fluid and strong bar for to meet the necessary weight prerequisites. These kinds of contamination in shrimp make a terrible picture for shrimp industry in abroad market. In this context Government should run awareness campaign of quality management of shrimp among the local stakeholders and build the advanced research centre for testing the quality of shrimp. L) In regard to the problem - 'Natural Calamities': The natural calamities like flood, salinity, Aila can fully destroy the brackish water fishery. Over rainfall can also change the salinity of the brackish water. In addition to communicating of meteorological forecasts at legitimate time over Radio and Television may lessen the possibility of accident.

\section{Conclusion}

Based on Principal Component Analysis (Rotated Component Matrix) of respective ranks given to the specified problems, the problem like 'Uncertain and non-remunerative Price (Depends on Prawn Size)' is the first priority, second priority is the 'High mortality rate and lack of virus screening facilities', third priority is the 'Land leasing problem' and fourth priority is the 'Brackish water facilities' to farmers cum Ghery/Bhery owners. The problems like 'Brackish water facilities' is the first priority, 'High mortality rate and lack of virus screening facilities' is the 
second priority, 'Land leasing problem' is the third priority and 'Labour Problem' is the fourth priority to the brackish water ghery/bhery owners. The problems like 'Uncertain and nonremunerative Price (Depends on Prawn Size)' is the first priority, 'Brackish water facilities' is the second priority, of the Brackish water Bhery's labour and other related workers. The problems like 'Financial Problems (Less opportunity of finance)' is the first priority, 'Land leasing problem' is the second priority, to the land leaser. The problems like 'Uncertain and non-remunerative Price (Depends on Prawn Size)' is the first priority, 'Embankment (River side bhery), Dyke (between two ghery/bhery) failure,' is the second priority, 'Brackish water facilities' is the third priority and 'High mortality rate and lack of virus screening facilities' is the fourth priority to Aratder/Moneylender and Traders and Wholesalers. However, irrespective of the local stakeholders of brackish water fishery the problems like Natural Calamities, Unethical practice, Lack of attention and contribution of the Government, Brackish water facilities, Financial Problems (Less opportunity of finance), Uncertain and non-remunerative Price (Depends on Prawn Size), Political disturbance, and Robbery/unsocial activities, are rank wise first component. Natural Calamities, Unethical practice, Lack of attention and contribution of the Government, Lack of attention and contribution of the Government, Brackish water facilities, Financial Problems (Less opportunity of finance), Uncertain and non-remunerative Price (Depends on Prawn Size), Political disturbance and Robbery/unsocial activities are rank wise first component. Labour Problem, High mortality rate and lack of virus screening facilities, Political disturbance, Land leasing problem and Brackish water facilities are rank wise for second component. Brackish water facilities, Embankment and Dyke between two ghery/bhery failure', and Land leasing problem are rank wise for third component.

\section{References}

1. Balakrishnan G, Soundarapandian P, Ramachandran K, Theivasigamani A, K, Savji, A, M, Chokkaiah, and P, Nataraj, (2011) Growth of Cultured White Leg Shrimp Litopenaeus Vannamei (Boone 1931) In Different Stocking Density; Advances in Applied Science Research, 2 (3): 107-113.www.pelagiaresearchlibrary.com

2. Flegel, T.W. 2006. Aquaculture 258: page no. 1-33.

3. Ghosh. A, and Chakraborty. P, K., (1989) "Aquaculture Status of Coastal West Bengal: It's Role in Economic Upliftment of Rural Poor" Naya Prakash, Calcutta, 1989.

4. Hora, S.L., (1952): Major problems of the fisheries of India. Journal of the Asiatic Society. Science. Voll-xviii, (1) 1952.

5. Kalawar A.G and Dandekar R.G, (1988): "Bright Prospect for Indian Fisheries" Journal of the Indian Fisheries Association 18. 1988, 167-178

6. P.S. Swathi Lekshmi, Chandrakandan, K, and Balasubramani, N., (2013): Perception of cost of shrimp culture technologies and policies affecting the adoption of shrimp culture technologies: A comparative study between shrimp farmers of Nellore and Nagapattinam; Indian Journal of Social Research Vol 54(4) (295-300) ISSN: 0019-5626.

7. Saha, G.N., Thakurta, S, C., Laha, G.C., Nandy, A.C., Karmakar, H, C., Naskar, K, R., Das, P, B., and Chatterjee, S, K., (1986): Ecology and fishery management of brackish water bheries in west Bengal, Bulletin no. 46, august 1986, central inland fisheries research institute (Indian Council of Agricultural Research)Barrackpore • west Bengal

8. Sharma, B.C. (1994): Lower Sunderban: Role of Fisheries in Sustainable Development. Asiatic Society. Kolkata.

9. Hand Book of Fisheries Statistics (2017-2018) Govt of West Bengal, Department of Fisheries, Directorate of Fisheries.

10. Office of the Joint director of Fisheries (ME\&MS), Govt of West Bengal, 60/A Colootala St. Kol-73. 